\title{
High School Exams
}

\author{
By MAREN Buvarp AARDAL
}

The message from the anonymous admin of the Facebook page "Chao Ming leaks Thanaweya Amma exams" is clear (WIRTSCHAFTER): Reform the educational system! The background for Chao Ming's celebrity is that the Facebook site [ $\nearrow$ Social Media], the fourth year in a row, is leaking high school exams and the correct answers for the multiple-choice tests. This year the leaking happens even before the exam has started. Some students are happy. When the exams are leaked, one student tells al-Fanār media, you do not even need to pay a teacher some 100 £E to give you the results via $\nearrow$ Mobile Phones during the exams [ オNormality = Heroism (Surviving) (WIRTSCHAFTER).

"Cheat," "leak," and "high school exam"- -whether in Arabic, French or English, the words seem to go together on YouTube, where dozens of videos from this year and before tell you how to cheat, what to avoid when cheating, how parliamentarians and authorities are trying to deal with it, etc. The consequence of the leaking is that several exams are postponed at the last minute. Egyptian students demonstrating in front of the Ministry of Education in Cairo and elsewhere are attacked by the police (EFFAT; al-Jazeera Arabic). Many parents seem to take their children's side - it is not these poor students' fault that the state repeatedly fails to prevent organized cheating. The students, as much as the parents, just want to get done with the exams now after an intensive year of study. The future educational enrolment for these students is exclusively based on the results of the high school exams, a system that is being heavily criticized. Students are also protesting in Tunisia, side by side with their teachers (BENLAKEHAL). Here, the reason for their discontent is the newly introduced reform that does nothing to decrease the number of lessons per day or the number of students in each class. The protesters demand a change to the curricula, a reduction of the amount of homework and an increase in teachers' salaries. A law preventing teachers from giving "l'étude" (private lessons) to students is not applied in practice, and a concerned teacher tells Nawaat how the police placed the burden of proof on her when she reported one of her colleagues who did not obey the law (HALI).

In Egypt, president Sisi assures the public that they will catch those leaking the exams, that he is as upset as everybody else about the problem and that everything will hopefully be fixed next year (Ahram Online; Misr Live). But this does not really help: even after the Ministry of Education publishes photos of the alleged perpetrators, states that twelve of its employees have been arrested for "wilful damage to the interest of the institution they work for, and [for] leaking the exams," and even after it has reported that 105 students will be referred to the Prosecutor General for violating the law, the leaks still continue on the popular website.

Sisi insists that they are prioritizing the youth, that the young are the future. There is a job to do. 24 per cent of Egyptians above the age of 15 do not know how to read and write (ABU L-GHAYT ). There are indeed signs that this percentage is decreasing, but illiteracy is still a big challenge. Approximately ten per cent of Egyptian children are not enrolled in school at all. In Nawwāra, a movie that depicts the stark contrasts between social classes in Egypt, a 
working-class woman takes her daughter out of school so that she can help her in serving the upper-class family living in a gated community [ $\lambda$ Gated Communities / Compounds].

Many families struggle hard to afford private tutoring for their children. Articles and reports about the sacrifices people make to enable their family members to succeed in the exams are read with the greatest interest. A two-year-old article about a mother of five who sells her body every Thursday in order to afford private tutoring lessons for her children still ranks among madàMașr's most read articles (OMAR). The woman works as a civil servant during the daytime, and a silent agreement with her husband, also a government employee, allows her to earn those extra pennies by the beginning of the weekend.

High school students in both countries, as well as the anonymous admin of the Chao Ming Facebook page, are asking for a reform of the educational system. After all, it is not the cheating that they regard as the main problem. Cheating is neither a new phenomenon nor specific to Egypt. The authorities, on the other hand, focus on quick fixes instead of discussing the structural causes of cheating, such as the quality of teaching, curricula promoting robotic learning, university enrolment procedures and work opportunities following graduation etc. A couple of months after the fiasco of the high school exams, the Egyptian Ministry of Education suggests introducing a new type of paper to be used in the exams in order to fight cheating. Now, students complain that this new paper will only make it more difficult for them to correct mistakes and elaborate their answers.

It does not improve the public's view of the Ministry of Education that the first Egyptian female ever to win a medal in the Olympics, the 18-year-old weightlifter Sara Samir, is not allowed to postpone her high school exams. According to the bronze medal winner, she asked the ministry in advance to postpone her exams to the second round in autumn so as not to lose focus on the Summer Olympics (al SHAYKH). The Ministry denies having received any such request from the ambitious student in advance.

One can only hope it gets better next year [ 7 Hope $v s$. Hell].

\author{
Related Entries \\ ARRAYS - Gated Communities / Compounds $\star$ Mobile Phones $\star$ Social Media \\ CODES - Hope vs. Hell \\ CODES COLLAPSED - Normality $=$ Heroism (Surviving)
}

\title{
References
}

\section{Written}

ABŪ L-GHAYṬ, Muḥammad. "Yā mujtama' al-15 \% nuqaddim lakum: Miṣr." al-Maṣrī al-Yawm (online), September 28, 2016, <http://www.almasryalyoum.com/news/details/1016135> (last accessed May 15, 2018).

[Ahram Online =] N. N. "75.7\% pass rate for Egypt's Thanaweya Amma exams: Minister." Al-Ahram, July 24, 2016, <http://english.ahram.org.eg/NewsContent/1/64/233899/Egypt/Politics-/-pass-ratefor-Egypts-Thanaweya-Amma-exams-Ministe.aspx> (last accessed May 14, 2018).

Benlakehal, Massinissa. "Students on strike: Why Tunisia's education reforms have run into trouble." Middle East Eye, November 30, 2016, <http:/www.middleeasteye.net/news/criticized-alleducational-reforms-tunisia-jeopardize-academic-year-613122003> (last accessed May 14, 2018).

jais • 21 (2021) - Themed Section In2016: *156-*158 
Effat, Habiba. "Students across Egypt protest postponement of thanaweya amma exams." madàMașr, July 28, 2016, <http://www.madamasr.com/news/students-across-egypt-protest-postponementthanaweya-amma-exams $>$ (last accessed May 15, 2018).

HALI, Abdel Aziz. "Interdiction des cours particuliers : M. Jelloul, votre décret est inapplicable!" Nawaat, November 3, 2016, <https://nawaat.org/portail/2016/11/03/interdiction-des-coursparticuliers-m-jelloul-votre-decret-est-inapplicable/> (last accessed May 14, 2018).

[al-Jazeera Arabic =] N. N. "Istimrār azmat tasrīb imtiḥanāt al-thānawiyya bi-Mișr." Published by AlJazeera Arabic, June 8, 2016, <http://youtu.be/1NxmAHO6QDk> (last accessed May 15, 2018).

[Misr Live =] N. N. "Shāhad awwal ta līq 'alà faḍịhat tasrīb imtiḥanāt al-thānawiyya al-āmma." Misr Live, June 29, 2016, <http://youtu.be/ZuCq_sRhHN4> (last accessed May 15, 2018).

OMAR, Said. "Selling pleasure, reaping hardship." madàMașr, December 2, 2016, <https://www madamasr.com/en/2014/11/26/feature/society/selling-pleasure-reaping-hardship/> (last accessed May 15, 2018).

al SнАүкн, Suhayla. "Sara Samir and the Sacrifices that Led to Her Olympic Bronze Medal Win". What Women Want, August 11, 2016, <http://whatwomenwant-mag.com/2016/08/11/sara-samirand-the-sacrifices-that-led-to-her-olympic-bronze-medal-win/> (last accessed May 14, 2018).

Wirtschafter, Jacob. "Leaked Questions and Answers Disrupt National Exams." Al-Fanar Media, June 11, 2016, <https://www.al-fanarmedia.org/2016/06/leaked-questions-and-answers-disruptnational-exams/> (last accessed May 15, 2018).

Movies

Nawwāra (Nawara). By Hāla Khalīl (Hala Khalil). Egypt 2016.

\marenaardal@gmail.com 